\title{
REDACTIONEEL
}

\section{Quo vadis?}

\author{
Hans Lindahl
}

Op 30 november 2018 kwam de Vereniging voor de Wijsbegeerte van het Recht in Nijmegen bijeen om haar honderdjarige bestaan te vieren. Het was een heuglijke gelegenheid, die vooral in het teken stond van een terugblik op de geschiedenis van de VWR alsmede een bezinning op haar toekomst. De bijeenkomst kon rekenen op prikkelende bijdragen van - in alfabetische orde - Mark Van Hoecke, Corjo Jansen, Bastiaan Rijpkema, Wouter Veraart en Pauline Westerman, die levendige discussies uitlokten onder de aanwezigen. Deze bijdragen worden opgenomen in dit nummer van het NJLP, samen met een column van Niels Graaf. Veel dank aan de vakgroep rechtsfilosofie van Nijmegen voor de gastvrijheid en uitstekende organisatie van deze bijeenkomst! Dank ook aan Anne Ruth Mackor voor haar zorgvuldige redactie van dit nummer van het NJLP.

Conform de Statuten van de VWR, stelt zij zich tot doel 'de beoefening van de wijsbegeerte van het recht en de rechtstheorie'. In wezen ging de bijeenkomst over deze bepaling, die twee vragen opriep. Ten eerste: Op welke manier is in het verleden dit doel opgevat en welke toekomstperspectieven heeft de rechtsfilosofie/rechtstheorie in het algemeen? Ten tweede: hoe dient de VWR zich in concreto te positioneren in het licht van deze ontwikkelingen? In plaats van in te gaan op de bijdragen afzonderlijk, maak ik graag gebruik van dit redactioneel om enkele in de bijdragen uitgewerkte standpunten omtrent deze twee vragen te melden en kort te bespreken.

Het centrale punt van discussie in de bijeenkomst betrof de specificiteit alsmede de verhouding van de rechtsfilosofie met betrekking tot de rechtspraktijk en, in mindere mate, tot de filosofie. De rechtsfilosofie staat niet alleen in haar wens om te filosoferen over een bepaald domein. Denk aan politieke filosofie, wijsgerige antropologie, wetenschapsfilosofie, esthetica, et cetera. Maar veel meer dan in andere wijsgerige branches onderhoudt de rechtsfilosofie een nauw verband met het domein dat ze bestudeert: de rechtspraktijk in brede zin. Dit is ook institutioneel het geval: nagenoeg alle rechtsfilosofen bevinden zich in faculteiten der rechtsgeleerdheid, niet in departementen wijsbegeerte. Dit levert een spanning op waarmee men op verschillende wijzen kan omgaan. Enerzijds wil de rechtsfilosofie indringend in gesprek gaan met de rechtspraktijk; anderzijds wil zij haar eigenheid als wijsgerige denkwijze niet verloochenen. Daar waar, in de woorden van Karl Larenz, de rechtsfilosofie een 'Reflexion auf eigenes Tun' is, is de spanning gering. Maar wanneer de rechtsfilosofie een specifiek academisch vakgebied wordt, met eigen leerstoelen en onderzoeksmiddelen, neemt de spanning toe: de denkwijze van de filosofie, óók als zij rechtsfilosofie is, sluit niet naadloos aan bij 
de juridische denkwijze, hetzij van een academische jurist, hetzij van een praktijkjurist stricto sensu. Zoals Westerman het treffend formuleert: het is niet de taak van de rechtsfilosoof om de grondslagen van het recht te articuleren, wat uiteraard niet uitsluit dat de rechtsfilosofie de rechtsdogmatiek vooruithelpt door haar begrippenkader, vooronderstellingen en politieke keuzes bloot te leggen en kritisch onder de loep te nemen.

Deze spanning is acuut geworden in drieërlei opzicht. Ten eerste: de professionalisering van de rechtsfilosofie en de toenemende academische publicatie-eisen die daarmee verbonden zijn, leiden ertoe dat rechtsfilosofen, vooral degenen die in een vroeg stadium van hun carrière staan, de voorkeur geven aan tijdschriftartikelen en monografieën die gericht zijn op hun vakgenoten, niet op de rechtspraktijk. Dit is overigens een issue voor alle rechtswetenschappers; in dat opzicht hebben we te maken met twee kanten van dezelfde medaille. Het desideratum van interdisciplinariteit ten spijt, blijft het monodisciplinaire vaktijdschrift en de monografie de boventoon voeren. De vraag is met andere woorden in hoeverre rechtswetenschappers uit andere disciplines bereid zijn om zelf het gesprek aan te gaan met de rechtsfilosofie vanuit hun eigen vakgebied in plaats van zich terug te trekken op hun eigen 'eilanden', gelet op de heersende monodisciplinariteit. Daarbij komt, ten tweede, dat de professionalisering van de rechtsfilosofie gepaard gaat met haar internationalisering, wat betekent dat men geneigd is om onderzoeksthema's op te zoeken die internationaal in zwang zijn. De poging om de wijsbegeerte van het recht los te koppelen van haar lokale wortels heeft paradoxalerwijze tot gevolg dat men één lokale vorm van rechtsfilosofie te bedrijven inruilt voor een andere: het Anglo-Amerikaanse debat (b.v. Hart - Dworkin, ideal non-ideal theory), dat intussen een hoge mate van steriliteit en irrelevantie bereikt heeft, zowel filosofisch als juridisch. Ten derde, de druk om competitieve externe onderzoekfinanciering binnen te halen versterkt de inspanningen, ja de noodzaak, van rechtsfilosofen om internationaal te publiceren, gelet op de configuratie van de beoordelingspanels van onderzoekfinancieringsinstanties. Juist deze internationale publicaties worden echter niet gezien of gelezen door de nationale rechtspraktijk.

Naast de spanning tussen rechtsfilosofie en rechtspraktijk is er ook een spanning tussen rechtsfilosofie en andere wijsgerige vakgebieden. Terwijl filosofen er niet aan twijfelen dat politieke filosofie, wetenschapsfilosofie, esthetica, et cetera wijsgerige domeinen zijn, zijn ze meestal terughoudender wat betreft de rechtsfilosofie, en niet alleen omdat zij meestal in faculteiten der rechtsgeleerdheid huist. Het lukt rechtsfilosofen goed om (internationaal) onderling in gesprek te treden; veel minder lukt het hen om filosofen van andere vakgebieden ervan te overtuigen dat het recht de filosofie - en niet alleen de rechtsfilosofie - met vragen confronteert die haar eigen vooronderstellingen en denkwijzen ter discussie kan stellen. De vraag is dan hoe rechtsfilosofie inzichtelijk kan maken wat de specifieke relevantie is van juridische ontwikkelingen voor wijsgerige vraagstukken, dus niet alleen een 'afnemer' te zijn van filosofische denkkaders. 
Kortom, onderzoeksbeleid van de rechtenfaculteiten in Nederland en Vlaanderen dient rekening te houden met de specifieke opdracht van de rechtsfilosofie, die een hecht doch kritisch verband met de rechtspraktijk wil houden maar eveneens ruimte wil hebben voor compromisloos filosoferen, ook wanneer dat niet verstaanbaar is voor praktijkjuristen.

Ten slotte is er de vraag naar het onderscheid tussen rechtsfilosofie en rechtstheorie, dat in het Engels doorgaans vertaald wordt als het onderscheid tussen philosophy of law en jurisprudence. Persoonlijk heb ik geen overtuigend criterium gevonden dat de twee helder onderscheidt. Wat mij belangrijk lijkt, is een herbezinning op de denk- en werkwijze van de rechtsfilosofie, een die haar in staat stelt om beter inzicht te verschaffen in de conceptuele, normatieve en institutionele dimensies van contemporaine rechtsontwikkelingen. Als een disciplinaire afbakening zinvol is, dan wellicht wat betreft het onderscheid tussen rechtsfilosofie en wat de Duitse rechtsdogmatiek treffend een 'algemene rechtsleer' noemt (wat mij betreft de kern is van het vak Encyclopedie van het recht).

Het is niet verwonderlijk dat deze spanningen terug te vinden zijn in de geschiedenis van de VWR en dat zij haar confronteren met de vraag hoe het verder kan en moet met de 'beoefening van de wijsbegeerte van het recht en de rechtstheorie'. De bijdrage van Corjo Jansen laat zien dat de VWR door verschillende fases is gegaan waarin de rechtsfilosofie aanvankelijk een zelfreflectie van de rechtspraktijk was en vervolgens een zelfstandige discipline werd die op afstand kwam te staan van de rechtspraktijk. Vooral dit laatste, zoals zijn betoog laat zien, is vanaf de jaren zestig van de vorige eeuw gaande, wat vooral zichtbaar is in de aard van de publicaties die verschenen zijn in het tijdschrift van de VWR, thans het NJLP.

De grote uitdaging voor de VWR is dat zij twee groepen belangstellenden moet zien te interesseren en hopelijk met elkaar (meer) in gesprek te laten treden: aan de ene kant professionele rechtsfilosofen die vaak - maar niet per se alleen - in dialoog willen treden met vakgenoten in de internationale arena, aan de andere kant praktijkjuristen die de verbinding van de rechtsfilosofie met concrete maatschappelijke issues zoeken, die actueel en relevant zijn voor Vlaanderen en Nederland.

De ontwikkeling die het NJLP heeft meegemaakt over de jaren heen weerspiegelt deze uitdaging, met als voorlopige uitkomst het nieuwe publicatiebeleid. Naast losse artikelen ambieert het tijdschrift om het jaar een internationaal en een maatschappelijk nummer. In het eerste richt het tijdschrift zich op het internationaal debat in de rechtsfilosofie; in het tweede gaan rechtsfilosofen en praktijkjuristen intensief in gesprek met elkaar over een hedendaags thema. Behalve de nieuwe richting van het tijdschrift is de VWR begonnen een bredere waaier aan activiteiten vorm te geven die haar aanwezigheid in en bijdrage aan de academie en de rechtspraktijk versterken. Dit betreft onder meer gezamenlijke activiteiten met de Vereniging voor de Sociaal-Wetenschappelijke bestudering van het Recht (VSR), de Staatsrechtkring en de Nederlandse Onderzoekschool Wijsbegeerte, alsmede een landelijk platform waarin promovendi in de rechtsfilosofie kennis kun- 
nen nemen van elkaars onderzoek en met elkaar een netwerk kunnen vormen. We verwachten dat dit tweesporig publicatiebeleid en de nieuwe verenigingsactiviteiten nieuw elan kunnen geven aan wat het betekent om de wijsbegeerte van het recht en de rechtstheorie te beoefenen.

Hans Lindahl 